UNCLASSIFIED

AEC RESEARCH AND DEVELOPMENT REPORT
HW-59193 REV

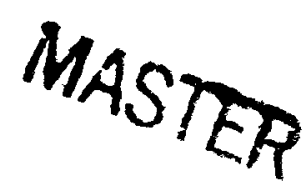

\title{
CONCENTRATION AND FINAL PURIFICATION OF NEPTUNIUM BY ANION EXCHANGE
}

\author{
J. L. RYAN
}

SEPTEMBER 3, 1959

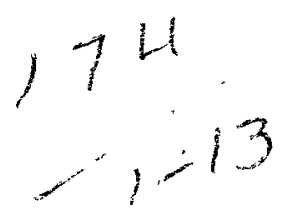

HANFORD ATOMIC PRODUCTS OPERATION RICHLAND, WASHINGTON

GENERAL ELECTRIC 


\section{DISCLAIMER}

This report was prepared as an account of work sponsored by an agency of the United States Government. Neither the United States Government nor any agency Thereof, nor any of their employees, makes any warranty, express or implied, or assumes any legal liability or responsibility for the accuracy, completeness, or usefulness of any information, apparatus, product, or process disclosed, or represents that its use would not infringe privately owned rights. Reference herein to any specific commercial product, process, or service by trade name, trademark, manufacturer, or otherwise does not necessarily constitute or imply its endorsement, recommendation, or favoring by the United States Government or any agency thereof. The views and opinions of authors expressed herein do not necessarily state or reflect those of the United States Government or any agency thereof. 


\section{DISCLAIMER}

Portions of this document may be illegible in electronic image products. Images are produced from the best available original document. 
CONCENTRATION AND FINAL PURIFICATION OF NEPTUNIUM BY ANION EXCHANGE

\title{
By
}

J. L. Ryan

Chemical Research

Chemical Research and Development Operation

September 3, 1959

A Revision of HW-59193, Issued February 10, 1959

\section{HANFORD ATOMIC PRODUCTS OPERATION RICHLAND, WASHINGTON}

Work performed under Contract No. AT $(45-1)-1350$ between the Atomic Energy Commission and General Electric Company

\author{
Printed by/for the U. S. Atomic Energy Commission
}

\author{
Printed in USA. Price $\$ 0.75$ Available from the \\ Office of Technical Services \\ U. S. Department of Commerce \\ Washington $25, \mathrm{D} . \mathrm{C}$
}




\section{CONCENTRATION AND FINAL PURIFICATION}

OF NEPTUNIUM BY ANION EXCHANGE

\section{INTRODUCTION}

The purification and concentration of plutonium by anion exchange in nitric acid has been exhaustively studied and its potential for decontamination of plutonium from fission products, uranium, and metallic impurities has been adequately demonstrated ${ }^{(1)}$. Because of this background and because of the similarity in chemistry of plutonium(IV) and neptunium(IV), only limited investigations have been carried out on the anion exchange behavior of neptunium(IV) in nitric acid $(2,3)$. These investigations have indicated the feasibility of anion exchange absorption of neptunium(IV) from nitric acid solution and have shown that its anion exchange properties are very similar in most respects to those of plutonium.

\section{OBJECTIVE}

The purpose of this report is to describe studies carried out on the separation and purification of neptunium from plutonium, uranium, fission products, thorium (including $\mathrm{Th}^{234}$ ), and common metallic impurities; and to define a process for carrying out these separations by means of anion exchange. In this work it is assumed that the anion exchange feed will always be greater than $0.1 \mathrm{~g} \mathrm{~Np} / 1$.

SUMMARY AND CONCLUSIONS

It was demonstrated that neptunium(IV) can be readily absorbed onto anion exchange resins from $6 \mathrm{MHNO}_{3}$ containing ferrous sulfamate and hydrazine or semicarbazide, separated from plutonium, uranium, and common metallic impurities by washing the resin at $25 \mathrm{C}$ with $6 \mathrm{MHNO}_{3}$ containing ferrous sulfamate and hydrazine or semicarbazide, separated from fission products and thorium by washing the resin at $60 \mathrm{C}$ with 8 $\mathrm{HNO}_{3}-0.01 \underline{\mathrm{M}} \mathrm{HF}$ containing hydrazine or semicarbazide, and eluted at 
concentrations greater than $40 \mathrm{~g} \mathrm{~Np} / 1$ with $0.35 \mathrm{MHNO}_{3}$ at $25 \mathrm{C}$. Decontamination factors of greater than 10,000 from uranium, plutonium, and common metallic contaminants, greater than 25,000 for fission products normally expected in the feed (mainly $\mathrm{Zr}-\mathrm{Nb}$ with some $\mathrm{Ru}-\mathrm{Rh}$ ), and greater than 1000 for thorium are obtainable under proper operating conditions.

Because of the low processing rates, the necessity for carrying out the absorption cycle at $25 \mathrm{C}$ and the absence of radiation damage problems, Dowex 1, X-4 (50 - 100 mesh) or Dowex 21K (50 - 100 mesh) resins are considered the best choices for this application. Gassing occurs with the use of ferrous sulfamate - semicarbazide reductant but is not a serious problem and does not occur with ferrous sulfamate - hydrazine reductant in 6 M $\mathrm{HNO}_{3}$. NEPTUNIUM ABSORPTION

In order for neptunium to be absorbed from nitric acid solution onto anion exchange resins, it is necessary that the neptunium be present in the +4 oxidation state. The standard oxidation potential ${ }^{(4)}$ of neptunium(IV) to neptunium( $(V)$ indicates that a fairly strong reducing agent is necessary to quantitatively reduce neptunium(V) to neptunium(IV) at one molar hydrogen ion concentration:

$$
\mathrm{Np}^{+4}+2 \mathrm{H}_{2} \mathrm{O} \rightarrow \mathrm{NpO}_{2}^{+}+4 \mathrm{H}^{+}+\mathrm{e}^{-} \quad \mathrm{E}^{\mathrm{O}}-0.739 \text { volt }
$$

Since the reduction of neptunium(V) to neptunium(IV) is dependent on the hydrogen ion activity to the fourth power and since nitrate complexing of neptunium(IV) tends to further promote reduction, neptunium is easily reduced to neptunium(IV) at the nitric acid concentrations of interest for anion exchange processing. Sheppard and Becker ${ }^{(2)}$ found that several reducing agents were satisfactory for preparing anion exchange feed. It was found that at $9 \mathrm{MHNO}_{3}$, even $\mathrm{NaNO}_{2}$ was capable of reducing about 90 per cent or more of the neptunium in solution to neptunium(IV).

As will be pointed out later, a stronger reducing system is necessary for the reduction and consequent separation of plutonium than is necessary for 
neptunium reduction. This reductant can be either a mixture of ferrous sulfamate and semicarbazide or ferrous sulfamate and hydrazine. Reduction of neptunium with either of these mixtures is quantitative and sufficiently rapid in the range $5-9 \underline{M} \mathrm{HNO}_{3}$. Solutions fed to anion exchange columns one hour after addition of the reductant gave initial breakthroughs of less than 0.01 per cent, indicating complete reduction in one hour.

The absorption behavior of neptunium was found to be very similar to that of plutonium ${ }^{(1)}$ with respect to the effects produced by variations of temperature, resin type, acidity, and uranium content. Resin shrinkage during the absorption cycle is about the same as that for plutonium (1) (about 0.15 per cent per gram per liter loading). Since it is necessary to operate the absorption step at $25 \mathrm{C}$ if separation from plutonium is desired, a resin showing good absorption kinetics is desirable. Neptunium processing does not require the high mass throughput and resulting high volume throughput that plutonium processing does, and because of this, 50 to 100 mesh resins are very satisfactory. The plutonium absorption data (1) indicated that Dowex 1, X-4 (50.- 100 mesh) or Dowex $21 \mathrm{~K}$ (50 - $100 \mathrm{mesh}$ ) would be the most satisfactory resins. Comparison of the breakthrough characteristics of Dowex 1, X-4 (50 - 100 mesh) and Permutit SK(30 - 50 mesh) at 25C from identical feed solutions and a flow rate of $1.0 \mathrm{ml} / \mathrm{min}, \mathrm{cm}^{2}(6 \mathrm{mg}$ $\mathrm{Np} / \mathrm{min}, \mathrm{cm}^{2}$ ) on $45 \mathrm{~cm}$ columns gave a capacity to 0.1 per cent breakthrough for Dowex 1, X-4 (50 - $100 \mathrm{mesh})$ of $51 \mathrm{~g} \mathrm{~Np} / 1$ resin; and for Permutit SK (30 - $50 \mathrm{mesh}$ ), of only $26 \mathrm{~g} \mathrm{~Np} / 1$ resin.

Some gassing in the resin bed occurs when processing neptunium reduced with ferrous sulfamate - semicarbazide mixture at $25 \mathrm{C}$ due to decomposition of the reductant. This does not seriously interfere with the efficiency of the absorption process if the resin bed is held down by mechanical means such as a spring-loaded screen. Using ferrous sulfamate hydrazine mixture as the reductant does not cause gassing at $6 \underline{\mathrm{M}}$ or lower $\mathrm{HNO}_{3}$ at $25 \mathrm{C}$. When plutonium separation is not required, neptunium may be 
loaded onto anion columns at $60 \mathrm{C}$ using semicarbazide only as reductant without gassing occurring. Loading at elevated temperature improves absorption rates in a manner similar to the effect of elevated temperature on plutonium absorption ${ }^{(1)}$.

REMOVAL OF COMMON METALLIC IMPURITIES, URANIUM, AND PLUTONIUM FROM NEPTUNIUM

The removal from the neptunium-loaded resin of common metallic impurities and uranium which are either not absorbed or very weakly absorbed by washing the loaded resin with nitric acid is exactly analagous to the removal of these impurities from plutonium by anion exchange (1) and does not warrant emphasis here. Decontamination factors from uranium of greater than 20,000 were obtained in loading neptunium from $5 \mathrm{M}$ and $6 \mathrm{MHNO}_{3}$ and washing with 20 column volumes of the same acid. The separation of plutonium from neptunium by anion exchange is an entirely different situation. Plutonium(IV) which is by far the most easily maintained valence state of plutonium in strong nitric acid is absorbed by the resin as strongly or slightly more strongly than neptunium(IV). In order to separate the plutonium from the neptunium by the same anion exchange step used to remove the other impurities, it is necessary to use reducing agents which will hold the plutonium in the unabsorbed plutonium(III) state.

Very few reducing agents that are capable of reducing plutonium are stable in strong nitric acid. Semicarbazide and hydrazine are both stable to strong nitric acid, and both are capable of reducing plutonium(IV) to plutonium(III). Both of these reductants are very slow in strong nitric acid, and their stability to the nitric acid is probably related to this fact. Because of their slowness in reduction of plutonium(IV) to plutonium(III) at the necessary acidities, however, they are by themselves unsuitable for separation of plutonium from neptunium. Ferrous ion (as ferrous sulfamate) is a very rapid reducing agent for plutonium because only a simple electron exchange 
is involved. The ability of Fe(II) to reduce plutonium(IV) is acid independent, but the destruction of ferrous sulfamate by nitric acid increases rapidly with increased acidity so that at the acidities desired for anion exchange loading, ferrous sulfamate will not hold plutonium(III) for a practical length of time. Since nitric acid oxidation generally proceeds through nitrite catalysis and since semicarbazide and hydrazine are both strong reductants and react fairly rapidly with nitrite, they are capable of stabilizing ferrous sulfamate and plutonium(III). Mixtures of ferrous sulfamate and semicarbazide or ferrous sulfamate and hydrazine reduce plutonium to plutonium(III) rapidly, as evidenced by the rapid appearance of plutonium(III) color, and hold it reduced for periods of several days in $8 \mathrm{M} \mathrm{HNO}_{3}$ at $25 \mathrm{C}$. It appears that the hydrazine mixture is the more stable, as shown by the persistence of plutonium(III) color for at least a month in $7.5 \mathrm{M}_{\mathrm{HNO}_{3}}$ at 25C. The stability of these reducing mixtures in nitric acid decreases markedly with increased temperature and because of this the feed and wash solutions should be kept at $25 \mathrm{C}$.

Oxidation of plutonium(III) to plutonium(IV) by nitric acid is favored by increased nitric acid concentration for two reasons. One of these is the increased oxidizing power of the more concentrated acid, and the other is increased nitrate complexing of the plutonium(IV) which shifts the equilibrium in favor of plutonium(IV). In the presence of anion exchange resin this shift is even more marked because of the very strong absorption of plutonium(IV) by the resin which, paralleling the increase in nitrate complexing, increases with increasing nitric acid concentration up to $7.5 \mathrm{M}$ It is obvious, therefore, that in order to achieve maximum separation of plutonium from neptunium by anion exchange, the resin loading and washing cycles should be carried out at the minimum acidity consistent with necessary resin capacity for neptunium. Based on plutonium absorption data $(1,5)$, the neptunium capacity of the resin at $25 \mathrm{C}$ can be expected to vary only slightly with acidity or neptunium concentration between 6.0 and $8,0 \mathrm{MHNO}_{3}$ if the 


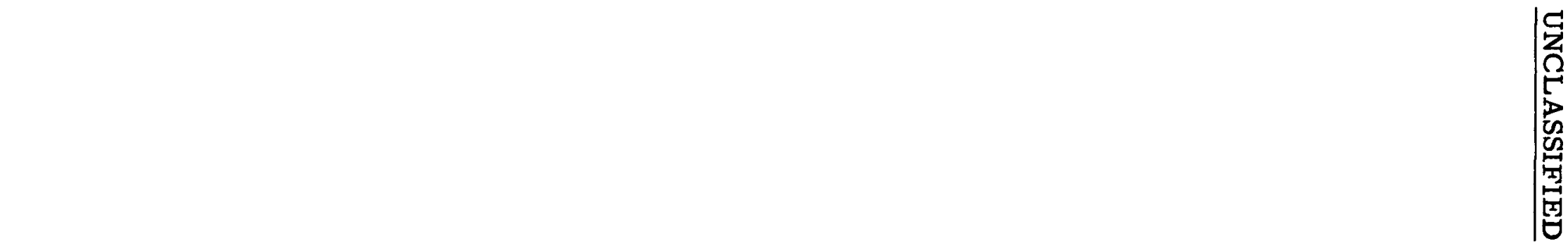

TABLE I

REMOVAL OF PLUTONIUM FROM NEPTUNIUM BY ANION EXCHANGE

Temperature $25 \mathrm{C}$

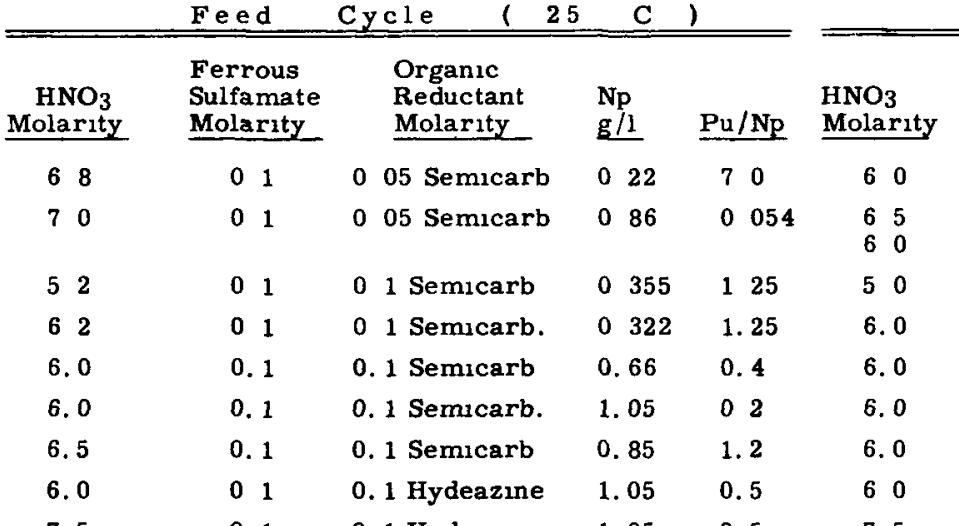

Wash

\section{Ferrous Organic}

Sulfamate Reductant Column * Flow Rate

Molarity Molarity

01005 Semicarb

0105 Semicarb

01005 Semicarb

01001 Semicarb

0.10 .1 Semicarb

$0.1 \quad 0.1$ Semicarb

0.10 .1 Semicarb.

0.101 Semicarb.

0.10 .1 Hydrazine

0.101 Hydrazine
Volumes

11

$\mathrm{ml} / \mathrm{min}, \mathrm{cm}^{2}$

35
6
6

6

40

4. 0

4. 0

5.0

70

8. 0

6.5

40

*Column Volume. Entire volume occupied by resin bed (resin beads and associated void spaces).

Product

w/o $\quad P u$ U

$41 \quad 175$

001

$<0 \quad 005>24,000$

$0.00265,000$

$0006 \quad 6,550$

$0.011 \quad 1,630$

$0.007 \quad 17,200$

$0.02611,700$

5.5 9.0 
The reduction of plutonium to plutonium(III) is an equilibrium situation ínvolving both nitric acid concentration (mainly through its effect on resin affinity for plutonium(IV)) and the $\mathrm{Fe}^{+++}$to $\mathrm{Fe}^{++}$ratio. It was found that during the absorption process, as might be expected, both increased acidity and increased $\mathrm{Fe}^{+++} / \mathrm{Fe}^{++}$increase resin plutonium absorption. Although this absorbed plutonium can be removed during the wash cycle, it results in lower resin neptunium capacity and necessitates a longer wash cycle. The high $\mathrm{Fe}^{+++}$to $\mathrm{Fe}^{++}$ratio results from two processes. First is the presence of large amounts of corrosion product iron in the impure neptunium feed stock. The second is the production of $\mathrm{Fe}^{+++}$through the reduction of the neptunium and plutonium. It is advisable, then, to use higher ferrous sulfamate concentration in the feed if the feed contains a large amount of iron or if the feed neptunium and/or plutonium concentrations are high. Some plutonium is always absorbed during the absorption cycle but due to the very low $\mathrm{Fe}^{+++}$to $\mathrm{Fe}^{++}$ratio in the wash, it is removed rapidly during the wash if the nitric acid is $6 \underline{M}$ or lower. Figure 1 shows the wash-off curve for plutonium from the resin by a $6 \mathrm{M}^{\mathrm{M}} \mathrm{HNO}_{3}, 0.1 \mathrm{M}$ ferrous sulfamate, 0.1 M semicarbazide solution. In processing some neptunium - feed stock it was found difficult to wash the last traces of plutonium out of the column. It is thought that this was due to the presence of finely divided solids, probably very high in plutonium, which were observed filtering out at the top of the column. This material probably resulted from concentrating the Purex plant solvent extraction product in the thermal plutonium concentrator prior to shipment to the anion exchange facility.

\section{REMOVAL OF FISSION PRODUCTS FROM NEPTUNIUM}

It was observed in the case of plutonium that when the feed and wash acidities are lowered below 7. $2 \mathrm{M}_{\mathrm{HNO}}$, the decontamination of the plutonium from fission product zirconium-niobium is markedly decreased (1). Since the neptunium-plutonium separation by anion exchange is based on a low acid loading and washing cycle, it can be expected that the fission product 


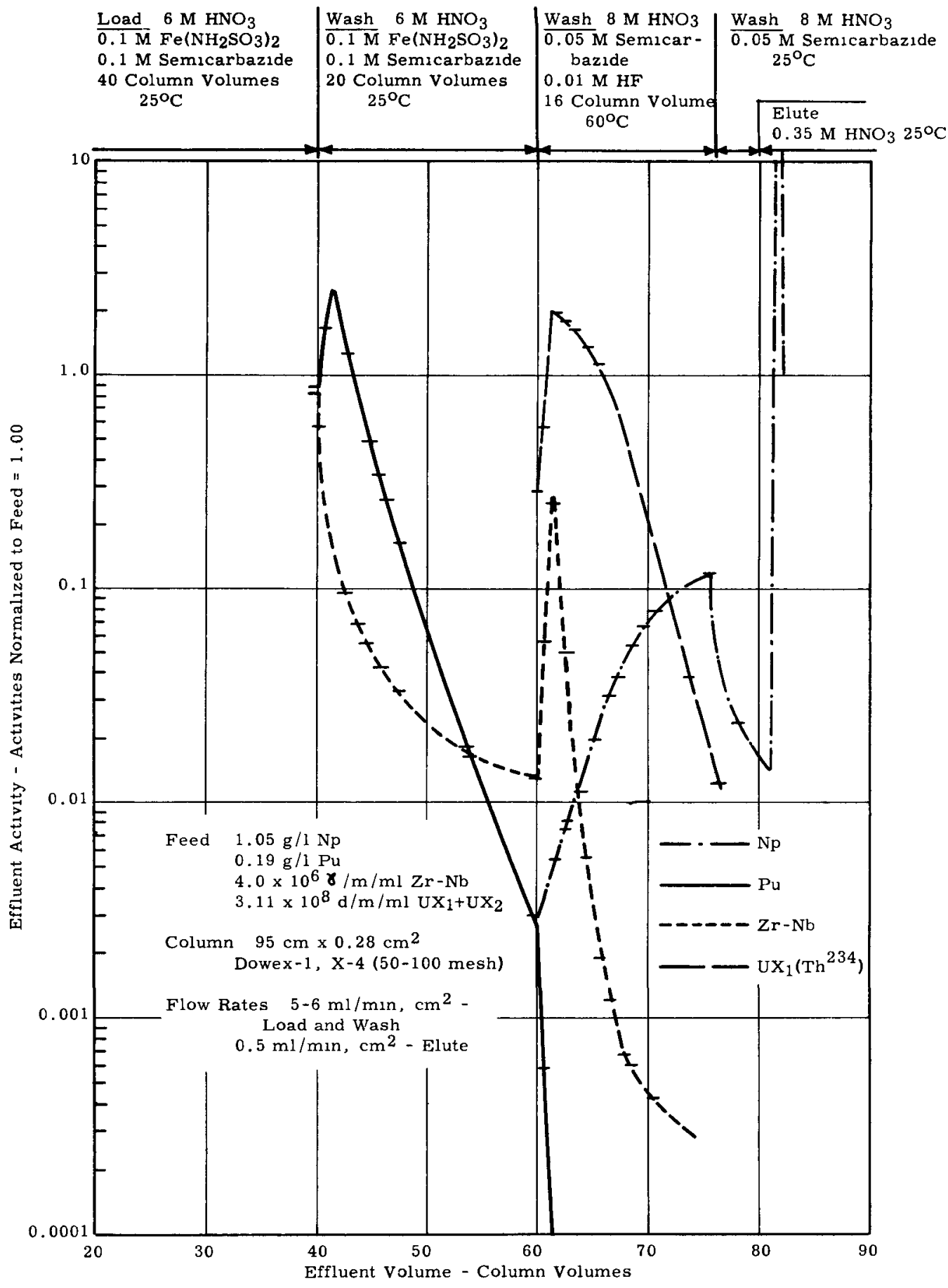
Plutonium, $\begin{gathered}\text { Fr-Nb, } \mathrm{Th}^{234} \text {, and Neptunium Washoff from } \\ \text { Neptunium Loaded Anion Resin }\end{gathered}$ 
decontamination will be poor. This was found to be the case. Loading neptunium at $25 \mathrm{C}$ onto Dowex $1, \mathrm{X}-4(50-100 \mathrm{mesh})$ from $5.2 \mathrm{M} \mathrm{HNO}_{3}$ and washing with 16 column volumes of $5 \underline{M} \mathrm{HNO}_{3}$ produced a zirconium-niobium decontamination factor of 38 and a ruthenium-rhodium decontamination factor of 260. Loading at $6 \underline{\mathrm{MHNO}}_{3}$ and washing with 32 column volumes of $6 \underline{\mathrm{M}}$ $\mathrm{HNO}_{3}$ followed by 16 column volumes of $8 \mathrm{M} \mathrm{HNO}_{3}$ produced a zirconiumniobium decontamination factor of only 75, indicating that high decontamination cannot be achieved by increasing the wash acidity after first loading at low acid.

The addition of fluoride to the wash cycle markedly improves the plutonium anion exchange fission product decontamination at elevated temperature but the use of fluoride at $25 \mathrm{C}$ was not studied ${ }^{(1)}$. The $25 \mathrm{C}$ washoff of fission products from neptunium loaded resin by fluoride wash was studied by loading a 95-centimeter column of Dowex 1, X-4 (50 - 100 mesh) at 25C from $6 \mathrm{M} \mathrm{HNO}_{3}$, washing the plutonium off with 20 column volumes of reducing $6 \mathrm{M} \mathrm{HNO}_{3}$ wash, and then washing with 15 column volumes of $8 \mathrm{MHNO}_{3}$, $0.01 \mathrm{MHF}$ at $25 \mathrm{C}$ and $3.2 \mathrm{ml} / \mathrm{min}, \mathrm{cm}^{2}$. The fluoride wash was made $8 \mathrm{molar}$ to minimize neptunium loss due to elution by fluoride. Optimum neptunium absorption occurs at $8 \mathrm{MHNO}_{3}$ and loss due to fluoride washoff should be at a minimum at this acidity. The zirconium-niobium decontamination factor was 790 , which is about a factor of 10 higher than that obtained with the straight $6 \underline{\mathrm{M}} \mathrm{HNO}_{3}$ wash at $25 \mathrm{C}$. The effect of addition of fluoride to the feed was studied by loading a column with neptunium from $8 \underline{\mathrm{M}} \mathrm{HNO}_{3}$ containing 0.005 $\underline{\text { M }} \mathrm{HF}$ and washing with 40 column volumes of $8 \underline{\mathrm{M}} \mathrm{HNO}_{3}, 0.005 \underline{\mathrm{M}} \mathrm{HF}$ at $25 \mathrm{C}$. The zirconium-niobium decontamination factor was 1,500 , which is only about two to three times that expected at $8 \mathrm{M}^{\mathrm{M}} \mathrm{HNO}_{3}$ at $25 \mathrm{C}$ in the absence of fluoride.

It appears, then, that in order to achieve the extremely high fission product decontamination factors reported for plutonium (1), it is necessary to operate the fluoride wash cycle at elevated temperature. A column of Dowex 1, X-4 (50 - 100 mesh) loaded from $6 \mathrm{MHNO}_{3}$ at $25 \mathrm{C}$ was washed with 
20 column volumes $6 \underline{\mathrm{MHNO}_{3}}, 0.1 \underline{\mathrm{M}}$ ferrous sulfamate, $0.1 \underline{\mathrm{M}}$ semicarbazide at $25 \mathrm{C}$ to remove plutonium. The column was then washed at $60 \mathrm{C}$ with 16 column volumes of $8 \mathrm{MHNO}_{3}, 0.05 \underline{\mathrm{M}}$ semicarbazide, $0.01 \mathrm{M} \mathrm{HF}$ to remove fission products. The washoff of zirconium-niobium in these two washes is shown in Figure 1 . No fission products were detected in the neptunium product, giving a zirconium-niobium decontamination factor greater than 70,000 and a ruthenium-rhodium decontamination factor greater than 4,000 .

\section{REMOVAL OF THORIUM FROM NEPTUNIUM}

Neptunium solvent extraction product from the Purex process has been found to contain a major fraction of the thorium impurity present in the uranium metal, including the extremely beta-active $\mathrm{Th}^{234}\left(\mathrm{UX}_{1}\right)$ and its associated 2. 3-mev beta-active daughter, $\mathrm{Pa}^{234}\left(\mathrm{UX}_{2}\right)$. Because of this high beta activity and the associated handling problems, it is necessary to separate the thorium from the neptunium. It would be quite advantageous to remove the thorium during the preliminary processing. If it is not removed, considerable simplification of the neptunium final purification would result if the thorium separation could be obtained during the anion exchange processing. This would eliminate the need for a separate thorium removal step.

Thorium is absorbed by anion exchange resins as a nitrate complex similar to plutonium and neptunium, but its distribution coefficient onto the resin is considerably lower than that for neptunium, $K_{D} T h=300^{(6)}$, and $\mathrm{K}_{\mathrm{D} \mathrm{Np}}=2400^{(2)}$ at from 7 to $8 \mathrm{M} \mathrm{HNO}_{3}$. Despite the lower distribution coefficient for thorium, the $\mathrm{K}_{\mathrm{D}}$ is still of sufficient magnitude to make it impractical to wash the thorium from the resin with strong acid. If the column is loaded at a reasonably slow flow rate, though, most of the thorium will be displaced by the neptunium and will concentrate at the front of the neptunium absorption band. During elution the thorium will be concentrated in the early fraction of the product, and substantial thorium decontamination can be 
achieved by collecting the first fraction of the product separately for rework. Collection of the first five per cent of the neptunium separately should give a thorium decontamination factor of about 10 or more on the remaining 95 per cent of the neptunium.

Much better decontamination from thorium can be obtained if the effect of its lower resin affinity is combined with the effect of a complexing agent in the wash solution which will complex thorium more strongly than neptunium. The formation constant for the first fluoride complex of thorium is $4.5 \times 10^{7}$ (7), whereas that for plutonium is only $5.9 \times 10^{6}$ (8). Since the ionic radius of $\mathrm{Np}^{+4}$ is much closer to that of $\mathrm{Pu}^{+4}$ than that of $\mathrm{Th}^{+4}$ (9), and since the known chemistry of neptunium(IV) is more similar to plutonium (IV) than to thorium(IV), it can be expected that fluoride complexing of neptunium will also be considerably weaker than fluoride complexing of thorium. It should be possible, then, to increase the removal of thorium from the resin by use of fluoride in the wash without markedly increasing neptunium loss.

An experiment was carried out in which a column of Dowex 1 , $\mathrm{X}-4$ (50 - $100 \mathrm{mesh})$ was loaded to an average of $40 \mathrm{~g} \mathrm{~Np} / 1$ resin with

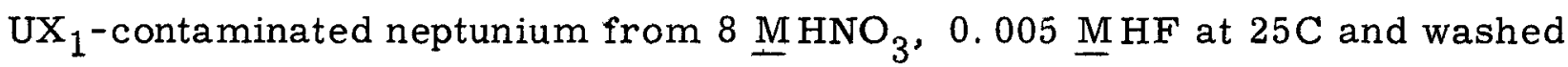
with 40 column volumes of $8 \mathrm{MHNO}_{3}, 0.005 \underline{\mathrm{M}} \mathrm{HF}$ at $25 \mathrm{C}$. The UX $\mathrm{H}_{1}$ decontamination factor was only 6,6. It was felt that this poor separation of thorium from the neptunium at $25 \mathrm{C}$ was due to poor kinetics of desorption by fluoride of the thorium from the neptunium-loaded, and therefore shrunken beads. The effect of an elevated temperature fluoride wash on thorium removal was studied in a run in which 40 column volumes of a $6 \mathrm{M} \mathrm{HNO}_{3}$ solution containing neptunium, plutonium, fission products, and $\mathrm{Th}^{2} 34\left(\mathrm{UX}_{1}\right)$ was fed to a 95 -centimeter column of Dowex $1, \mathrm{X}-4$ (50-100 mesh) using $0.1 \mathrm{M}$ ferrous sulfamate and $0.1 \mathrm{M}$ semicarbazide as reductant. The column was washed at $25 \mathrm{C}$ with 20 column volumes of reducing $6 \mathrm{MHNO}_{3}$ for plutonium removal, followed by 16 column volumes of $8 \underline{\mathrm{MHNO}} \mathrm{H}_{3}$, 
$0.05 \mathrm{M}$ semicarbazide, $0.01 \mathrm{MHF}$ at $60 \mathrm{C}$. The washoff of thorium by the $60 \mathrm{C}$ fluoride wash is shown in Figure 1, along with the washoffs of plutonium and zirconium-niobium, previously discussed. The collection of neptunium product was started well before the neptunium elution band reached the bottom of the column to insure that the residual $\mathrm{UX}_{1}$ would be in the product. The resultant thorium decontamination factor was 1,380 . No studies were made on the effect of fluoride concentration on rate of thorium removal.

Loss of plutonium from plutonium-loaded resin to the fluoride wash has been observed (1). About the same loss was observed with neptunium. Two methods have been demonstrated with plutonium to minimize this loss ${ }^{(1)}$. One is to decrease resin loading, leaving more excess resin at the bottom of the column; the other is to add aluminum to complete with the fluoride complexing of the absorbed actinide. The use of aluminum was not tried in the case of neptunium, but its effect on fission product removal is probably slight, as in the case of plutonium. Its effect on thorium removal by fluoride remains to be determined. The neptunium loss to the waste is shown in Figure 1 along with the washoff of plutonium, fission products, and thorium. No loss occurs except in the $60 \mathrm{C}$ fluoride wash. In the case of Figure 1 the column was 95 centimeters long and the average column loading of $40 \mathrm{~g} \mathrm{~Np} / 1$ resin allowed only about 15 centimeters of excess unloaded resin. Over all waste loss was 2.1 per cent. In order to hold waste loss below 0.5 per cent it would probably be necessary to terminate the $6 \mathrm{MHNO}_{3}$ loading when the average column loading is about 25 to $30 \mathrm{~g} \mathrm{~Np} / 1$ resin. Neptunium lost to the fluoride waste could be readily recovered on a second recovery column, especially if excess aluminum were added to the solution before passing it into the second column.

NEPTUNIUM ELUTION

Neptunium elution from Dowex 1, X-4 (50 - 100 mesh) and Dowex $21 \mathrm{~K}(50-100$ mesh) is very similar to plutonium elution except in two 
respects. These are: 1) better elution kinetics and 2) relative instability of neptunium(IV) in dilute nitric acid. Elution with $0.35 \mathrm{MHNO}_{3}$ at $25 \mathrm{C}$ is faster than in the case of plutonium. This allows elution at $25 \mathrm{C}$ at flow rates up to $0.5 \mathrm{ml} / \mathrm{min}, \mathrm{cm}^{2}$ with little tailing. Higher flow rates produce tailing and flow rates above about $1 \mathrm{ml} / \mathrm{min}, \mathrm{cm}^{2}$ are unsatisfactory. Neptunium is eluted at $25 \mathrm{C}$ by $0.35 \mathrm{MHNO}_{3}$ as neptunium(IV), as determined coulometrically on the product immediately after elution (less than 45 minutes). On standing overnight the product in the absence of a holding reductant (reductant washed out of column thoroughly before elution) oxidizes quantitatively to neptunium(V) with a trace of neptunium(VI). The maximum product concentration attainable under such conditions appears to be about $60 \mathrm{~g} / \mathrm{l}$ similar to that of plutonium. If the neptunium is eluted at elevated temperature (greater than $50 \mathrm{C}$ ), oxidation to neptunium(V) occurs rapidly in the column in the $0.35 \mathrm{M}$ acid of elution. Since neptunium(V) does not enter into the resinsolution equilibrium, the product concentration can become quite high.

Elution of the entire product from 80 -centimeter columns at an average concentration of greater than $80 \mathrm{~g} \mathrm{~Np} / 1$ was achieved. Unfortunately this oxidation of the neptunium causes severe gassing and for this reason elevated temperature elution may be undesirable. No gassing occurs in elution as neptunium(IV) at $25 \mathrm{C}$.

\section{NEPTUNIUM PURIFICATION FLOWSHEET}

Figure 2 shows a flowsheet for the purification of neptunium by anion exchange. This is the same as the flowsheet used to produce the washoff curves of Figure 1 except for the use of hydrazine instead of semicarbazide and the lower recommended column loading. The loading flow rate of $10 \mathrm{mg} \mathrm{Np} / \mathrm{min}, \mathrm{cm}^{2}$ is about the maximum for satisfactory operation on 3to 6 -foot columns and would amount to a loading rate of $100 \mathrm{~g} \mathrm{~Np} / \mathrm{hour}$ on a 6 -inch by 6 -foot column. A resin loading of 25 to $30 \mathrm{~g} \mathrm{~Np} / 1$ resin on a 6 -inch by 6 -foot column amounts to processing of 800 to 1000 grams of neptunium per batch. The use of a reducing agent during the fluoride wash may be 


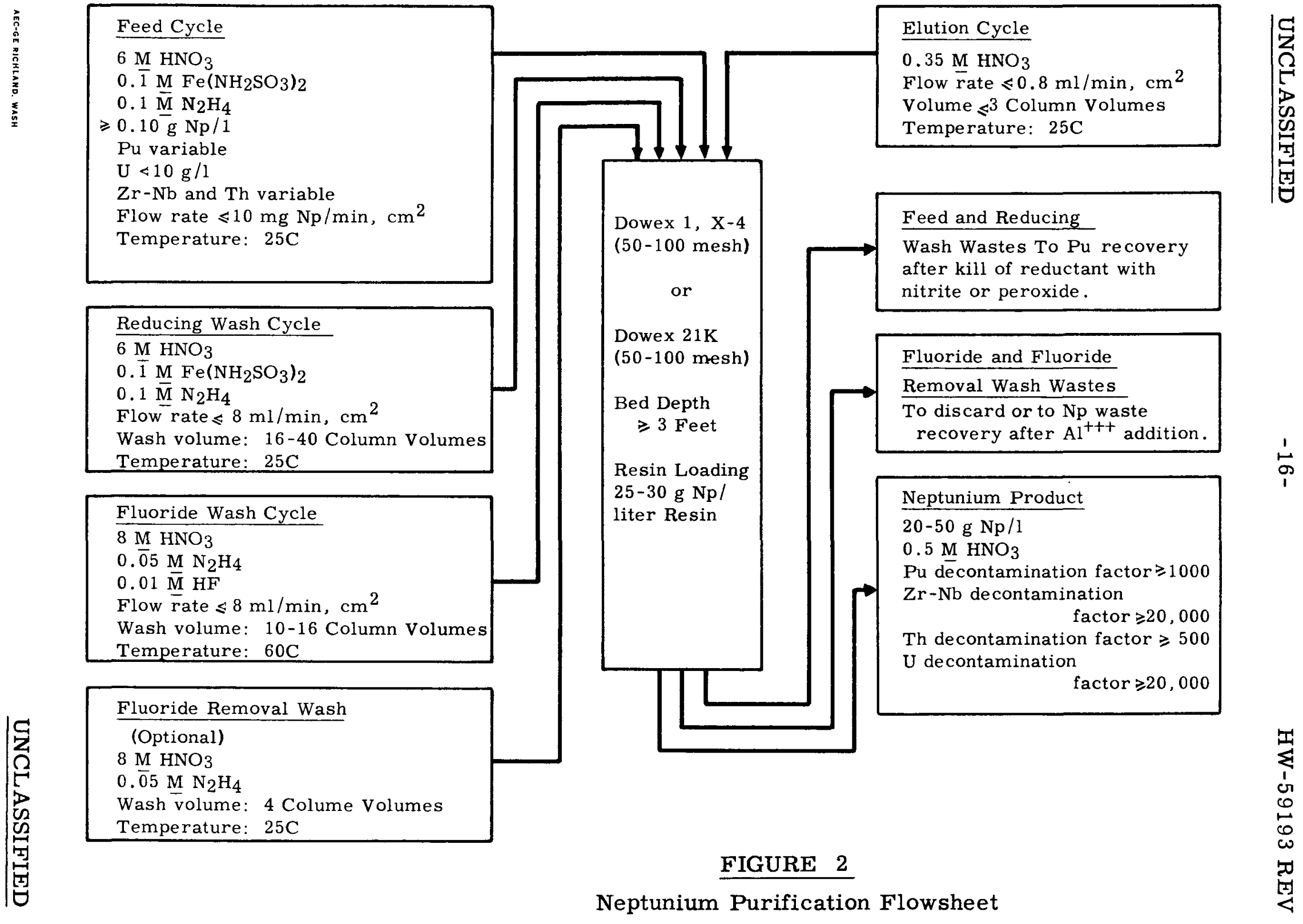


unnecessary but is added as a safety factor. The fluoride removal wash shown in Figure 2 is optional and is unnecessary if traces of fluoride in the product are not objectionable. The volume of wash solution is variable, depending on the decontamination factors desired and the efficiency of the equipment in terms of channeling, etc. The decontamination factors for given wash conditions can be predicted from washoff curves similar to those of Figure 1. The neptunium product concentration will depend on how sharply the cut to and from the product receiver is made at the front and tail of the neptunium elution, but average product concentrations of greater than $40 \mathrm{~g} \mathrm{~Np} / 1$ are attainable at a flow rate of less than or equal to $0.5 \mathrm{ml} / \mathrm{min}$, $\mathrm{cm}^{2}$.

The use of hydrazine instead of semicarbazide is recommended for three reasons. It is cheaper, gassing does not occur when it is used in conjunction with ferrous sulfamate at $6 \mathrm{M} \mathrm{HNO}_{3}$, and it is simpler to store. Semicarbazide, a solid, must be stored under refrigeration, whereas hydrazine is supplied as a 35 per cent ( $11 \mathrm{M})$ solution, stable at room temperature.

Since the reducing power of mixed hydrazine - ferrous sulfamate in $6 \mathrm{MHNO}_{3}$ decreases with time due to decomposition, the feed and reducing wash should be made up as soon as possible before use, with the exception that the reductants should be added to the feed about one hour before use to insure adequate time for neptunium reduction. The reducing loading and wash cycles must operate at low temperature so provision must be made for cooling the acid-adjusted feed and wash to $25 \mathrm{C}$ before adding the reductants. Otherwise heat of dilution of the acid will cause rapid decomposition of the reductants. Because the ferrous sulfamate alone is very unstable to the strong nitric acid, it should be added in solution with the stabilizing reductant. With semicarbazide this may be done by dissolving the semicarbazide directly in the ferrous sulfamate solution before addition. Hydrazine is a strong base and 
must first be neutralized with nitric acid and cooled before mixing with ferrous sulfamate, since the heat of neutralization liberates a large amount of heat. The neutral or slightly acid hydrazine nitrate solution is stable and may be made up some time before use to allow cooling.

\section{BIBLIOGRAPHY}

1. Ryan, J. L. and E. J. Wheelwright. The Recovery, Purification and Concentration of Plutonium by Anion Exchange in Nitric Acid, HW-55893. January, 1959.

2. Sheppard, J. C. and G. V. Becker. HAPO, personal communication.

3. Savannah River Laboratory, Technical Division. Monthly Progress Reports, DPST-57-1-3. March 1957---.

4. Seaborg, G. T. and J. J. Katz. The Actinide Elements, Natl. Nuclear Energy Ser., Div. IV, Vol 14A: New York: McGraw-Hill, 1949.

5. Durham, R. W. and R. Mills. The Absorption of Plutonium by Anion Resins, Part I: Equilibrium Studies, CEI-62. September, 1953.

6. Danon, J. "Absorption of Thorium by Anion Exchange Resins from Nitric Acid Media", J. Am. Chem. Soc. 78: 595 3-54. 1956.

7. Dodgen, H. W. and G. K. Rollefson. "The Complex Ions Formed by Iron and Thorium with Fluoride in Acid Solution", J. Am. Chem. Soc. 71: 2600-07. 1949.

8. McLane, C. K The Transuranium Elements, Natl. Nuclear Energy Ser. Div. IV, Vol. 14B: Paper 4.8, 414-22. New York: McGraw-Hill, 1949.

9. Seaborg, G. T. and J. J. Katz. The Actinide Elements, Natl. Nuclear Energy Ser. Div. IV, Vol. 14 A: New York: McGraw-Hill, 1949. 


\section{INTERNAL DISTRIBUTION}

Copy Number

$\begin{array}{ll}1 & \text { R. J. Brouns } \\ 2 & \text { J. S. Buckingham } \\ 3 & \text { L. P. Bupp } \\ 4 & \text { V. R. Cooper } \\ 5 & \text { K. M. Harmon } \\ 6 & \text { M. K. Harmon } \\ 7 & \text { H. H. Hopkins } \\ 8 & \text { E. R. Irish } \\ 9 & \text { W. E. Keder } \\ 10 & \text { R. L. Moore } \\ 11 & \text { J. M. Nielsen } \\ 12 & \text { W. H. Reas } \\ 13 & \text { F. P. Roberts } \\ 14 & \text { J. L. Ryan } \\ 15 & \text { W. H. Swift } \\ 16 & \text { E. E. Voiland } \\ 17 & \text { M. T. Walling, Jr. } \\ 18 & \text { E. J. Wheelwright } \\ 19 & \text { 300 File } \\ 20 & \text { Record Center } \\ 21-23 & \text { Extra } \\ 24-27 & \text { G. E. Technical Data Center, Schenectady }\end{array}$


(TID-4500, 15th Ed.)

\section{EXTERNAL DISTRIBUTION}

Number of Copies

2

1

1

1

2

2

2
Aberdeen Proving Ground

Aerojet-General Corporation

Aerojet-General, San Ramon (IOO-880)

AFPR, Boeing, Seattle

AFPR, Lockheed, Marietta

Air Force Special Weapons Center

ANP Project Office, Convair, Fort Worth

Alco Products, Inc.

Allis-Chalmers Manufacturing Company

Argonne Cancer Research Hospital

Argonne National Laboratory

Army Ballistic Missile Agency

Army Chemical Center

Army Medical Research Laboratory

Army Signal Research and Developi..lent Laboratory

Atomic Bomb Casualty Commission

AEC Scientific Representative, Japan

Atomic Energy Commission, Washington

Atomics International

Babcock anci Wilcox Company (NYOO-1940)

Battelle Memorial Institute

Bettis Plant

Brookhaven National Laboratory

BAR, Grumman Aircraft, Bethpage

Bureau of Medicine and Surgery

Bureau of Mines, Salt Lake City

Bureau of Ships (Code 1500)

Chicago Operations Office

Chicago Patent Group

Columbia University (Failla)

Combustion Engineering, Inc.

Committee on the Effects of Atomic Radiation

Convair-General Dynamics Corporation, San Diego

Defence Research Member

Denver Research Institute

Department of the Army, G-2

Division of Raw Materials, Washington

duPont Company, Aiken 
HW-59193 REV

UC-7, Chemistry - Radiation and Radiochemistry (TID-4500, 15th Ed.)

EXTERNAL DISTRIBUTION (Contd.)

Number of Copies

duPont Company, Wilmington

Edgerton, Germeshausen and Grier, Inc., Las Vegas Frankford Arsenal

General Electric Company (ANPD)

General Electric Company, St. Petersburg

Goodyear Atomic Corporation

Grand Junction Operations Office

Hawaii Marine Laboratory

Iowa State College

Jet Propulsion Laboratory

Knolls Atomic Power Laboratory

Los Alamos Scientific Laboratory

Mallinckrodt Chemical Works

Maritime Administration

Martin Company

Massachusetts Institute of Technology (Hardy)

Monsanto Chemical Company

Mound Laboratory

National Aeronautics and Space Administration, Cleveland

National Bureau of Standards

National Bureau of Standards (Library)

National Lead Company, Inc., Winchester

National Lead Company of Ohio

Naval Civil Engineering Laboratory

Naval Medical Research Institute

Naval Research Laboratory

New Brunswick Area Office

New York Operations Office

Nuclear Development Corporation of America

Nuclear Metals, Inc.

Oak Ridge Institute of Nuclear Studies

Office of Naval Research

Office of Naval Research (Code 422)

Office of Ordnance Research

Office of Quartermaster General

Office of the Surgeon General

Ordnance Materials Research Office 
UC-7, Chemistry - Radiation and Radiochenistry (TID-4500, 15th Ed.)

EXTERNAL DISTRIBUTION (Contd.)

Number of Copies

$\begin{aligned} 1 & \text { Ordnance Tank-Automotive Command } \\ 1 & \text { Patent Branch, Washington } \\ 4 & \text { Phillips Petroleum Company (NRTS) } \\ 1 & \text { Picatinny Arsenal } \\ 1 & \text { Power Reactor Development Company } \\ 2 & \text { Pratt and Whitney Aircraft Division } \\ 1 & \text { Princeton University (White) } \\ 2 & \text { Public Health Service } \\ 1 & \text { Public Health Service, Savannah } \\ 1 & \text { Sandia Corporation, Albuquerque } \\ 1 & \text { Sylvania Electric Products, Inc. } \\ 1 & \text { Technical Research Group } \\ 2 & \text { Union Carbide Nuclear Company (ORGDP) } \\ 5 & \text { Union Carbide Nuclear Company (ORNL) } \\ 1 & \text { Union Carbide Nuclear Company (Paducah Plant) } \\ 1 & \text { USAF Project RAND } \\ 1 & \text { U. S. Geological Survey, Denver } \\ 1 & \text { U. S. Geological Survey, Naval Gun Factory } \\ 1 & \text { U. S. Geological Survey, Washington } \\ 1 & \text { U. S. Naval Postgraduate School } \\ 1 & \text { U. S. Naval Radiological Defense Laboratory } \\ 1 & \text { U. S. Patent Office } \\ 1 & \text { University of California at Los Angeles } \\ 2 & \text { University of California, Berkeley } \\ 2 & \text { University of California, Livermore } \\ 1 & \text { University of Puerto Rico } \\ 1 & \text { University of Rochester } \\ 1 & \text { University of Utah } \\ 1 & \text { University of Washington (Donaldson) } \\ 1 & \text { Walter Reed Army Medical Center } \\ 1 & \text { Watertown Arsenal } \\ 1 & \text { Westinghouse Electric Corporation (Schafer) } \\ 3 & \text { Wright Air Development Center } \\ 75 & \text { Technical Information Service Extension } \\ & \text { Office of Technical Services, Washington } \\ & \end{aligned}$

